search of food. Information as to the places in which such shoals are likely or unlikely to be found is thus of real value to fishermen wishing to intercept them. Work in this direction was described in the third and fourth papers of the Norwich symposium. Ingenious instruments and methods have been used in a comprehensive and continuous survey of the floating animal and plant plankton of the North Sea with relation to the movements of herring. Positive correlations between the number of herring caught and their food Calanus, and negative correlations with phytoplankton, have already been demonstrated. The practical outcome of this is that fishermen can be assured of a greater return for a season's labour if they will regularly use a plankton indicator in deciding where to set their nets. It has also been shown that the phytoplankton at times forms dense patches which interfere with the movements and shoaling of herring, with serious consequences to the dependent fisheries. The study of the origin, disposition and fate of these patches, therefore, is in itself of major interest to the industry. We must also know whether the observed tendency for the autumn herring shoals. of both 1933 and 1934 to mass against the edge of a diatom patch is a regular phenomenon.

A word or two must suffice to deal with a line of investigation about which the symposium was silent. Nothing was said regarding the urgent necessity of a greatly improved market for herrings, to prevent the complete collapse of the British industry. For of what use to the fishermen is scientific aid in his fishing if he cannot sell the catches he is already making without such aid?

E. FORD.

\title{
Erosion Surfaces
}

GINCE Ramsay recognised in 1878 that the $S$ even skyline of South Wales represented a plain of marine denudation, uplifted and dissected, upland surfaces of low relief have been recognised in all parts of the world, and their probable relation to the great unconformities of the stratified rock succession has been discussed. Some, following W. M. Davis, have preferred to regard them as sub-aerial peneplains rather than marine features, but few certain criteria exist for distinguishing subaerial from submarine surfaces, after uplift and dissection, and each case must be judged on its merits. Recent years have witnessed a concentration of interest upon such features, commonly known as 'platforms'. In America, the work of the late Joseph Barrell, and of D. W. Johnson, has emphasised the importance of this line of study. A committee of the International Geographical Congress, on which Prof. A. G. Ogilvie is the British representative, is at present seeking to organise the work of mapping erosion surfaces in Europe, using an agreed, though tentative, scheme of symbols. Interest has also been fostered by the publication of Prof. Baulig's recent monograph $^{\mathbf{1}}$ in which high-level platforms are discussed in the context of the daring theory of major eustatic changes of sea-level.

With the field thus fertilised, Sections C (Geology) and E (Geography) devoted a session to a joint symposium and discussion on "Denudation Chronology" at the Norwich meeting of the British Association on September 9. The regions discussed included south-east England, Devon and
Somerset, South Wales, southern Ireland, the East Midlands, Yorkshire and the Channel Islands. Any attempt fully to correlate work from so wide an area would be premature, but a most welcome concurrence of opinion was manifest both as to the methods of research and the general results obtained. The histories of denudation in the several areas proved indeed so generally comparable as to point a most hopeful future for such investigation and to foreshadow theoretical results of high importance.

An initial problem to be solved in most areas is the differentiation of older surfaces-stripped planes of unconformity, from those formed during the middle and later portions of Tertiary time. There is a general tendency among the students of the older rocks tacitly to underestimate the erosional work of Tertiary time, and to regard the dominant hill-top surfaces of relict Palæozoic uplands as the basal planes of Triassic, Jurassic or Cretaceous rocks, which, buried far beneath the adjoining plains, rise to join the hill-top surface of the 'Massifs', thus signifying a former wide extension of the sediments above them. So cavalier a dismissal of some sixty million years of geological work is theoretically unacceptable, and as a hypothesis it fails to fit the facts. Wherever they are examined in Britain, the 'fossil peneplains' of pre-Permian to pre-Cretaceous date are relatively steeply inclined away from the Palæozoic uplands. Even if their slope flattened as traced away from the heavily loaded areas of the plains, they must nevertheless have passed far above the 
existing hill-top surfaces, having, in general, been destroyed in cycles of erosion which ran their course before the current cycle or its immediate predecessor. Recent American work points to a similar conclusion. The Schooley peneplain which bevels many of the summits of the Northern Appalachians was formerly regarded as a landward continuation of the surface below the coastal plain sediments (the fall zone peneplain). D. W. Johnson gives good reasons for supposing that it is a much later feature', probably not younger than Early Tertiary.

These considerations enforce the necessity of beginning work on any general scheme of denudation chronology in south-east England, where surfaces can be dated by reference to known Tertiary deposits. There are two major surfaces in this region: $(a)$ the folded sub-Eocene surface, which emerges from beneath its sedimentary cover on the lower slopes of the chalk round the margins of the London and Hampshire Basins, and $(b)$ the mid-Tertiary (probably late Miocene) surface which forms the general hill-top plane of the south-east, bevelling the escarpments. Most of the true clay-with-flints rests on this latter surface, which was locally warped down before uplift to admit a Pliocene sea over parts of the area. It is hence difficult in places to distinguish between the late Miocene sub-aerial peneplain and the sub-Pliocene marine surface, largely stripped of its thin veneer of sand and shingle. Later, less extensive, surfaces of Pliocene and Pleistocene date-in reality old valley floors-can be traced throughout the region, and the record is supplemented and confirmed by the testimony of cyclic river-profiles, which reveal former sea-levels, closely comparable with those deduced by J. Hanson-Lowe in the Channel Islands. It cannot be too strongly emphasised that the whole southeastern region (excluding the margins of the unstable North Sea depression) has evolved under the influence of uniform changes of base-level, during its later history. The last traceable act of warping was that which slightly deformed the late Miocene peneplain.

The two major surfaces noted above represent periods of erosion so protracted that corresponding features should certainly be distinguishable in the uplands of the north and west. In south-west England a convenient upper datum in time is provided by the Pliocene marine notch and associated coastal ledge at about $400 \mathrm{ft}$. O.D. This is unwarped, but the Early Tertiary (pre-Oligocene) surface is evidently largely warped or faulted, as witnesses its depression to low levels along a zone running from Bideford Bay via Petrockstow and the Moretonhamstead syncline to the Bovey Tracey basin. Nevertheless, it may conceivably be represented by the sloping hill-top surface of parts of Exmoor and the Brendon Hills $(1,100$ $1,400 \mathrm{ft}$.). At lower elevations, there is a 900 $1,000 \mathrm{ft}$. platform and a well-marked very uniform surface which dominates central Devon, ranging in height from $600 \mathrm{ft}$. to $800 \mathrm{ft}$. One of these surfaces, probably the latter, is to be identified with the Miocene peneplain of the south-east.

Comparable features have been investigated by A. A. Miller in South Wales and South Ireland. In both regions he finds a sloping surface extending from low levels near the coast to an upper limit at $800-900 \mathrm{ft}$. This might be interpreted as the product of an advancing or a retreating sea, or even as a sub-aerial feature. It should be added that Prof. Trueman and Miss Goscar find some evidence in South Wales that the general profile is 'stepped' or composite in places, revealing separate platform levels, at $200 \mathrm{ft}$., $400 \mathrm{ft}$. and $600 \mathrm{ft}$., and Miller's work on the river-profiles and the wind-gaps lends some support to such an idea.

In northern England, Prof. H. H. Swinnerton has recognised a high-level surface in south Derbyshire, possibly the sub-Cretaceous plane, but more probably, in the light afforded by the other regions, an early Tertiary feature. Lower platforms representing stages in the excavation of the Trent valley fall into a series generally comparable with those of the Thames valley. Of particular interest has been the discovery by Dr. H. C. Versey, following J. W. Stather and others, of probable early Tertiary deposits on the higher parts of the Yorkshire wolds. These rest on a surface which appears to be traceable in the North York Moors and also, though less certainly, in the Pennine region.

In conclusion, it may be remarked that the study of erosion surfaces is far from being of purely academic interest. From the geological point of view, such surfaces afford a record complementary to that of deposition, but there is a geography as well as a geology of surfaces. Recognition and delimitation of landscape facets is an essential part of geographical analysis, if only because of their influence on soil character and landutilisation. It is clearly a matter of first import. ance whether a surface retains relics of an Eocene, Cretaceous or other covering, recently removed, or is mantled by a strongly leached regolith exposed to the atmosphere since Middle or Early Tertiary times. Many agricultural contrasts in Britain can be explained on these lines, and whether in conducting soil-surveys or planning the improvement of agricultural land, such facts should receive full attention.

S. W. WOOLDRIDGE.

\footnotetext{
${ }^{1}$ Institute of British Geographers. Publication No. 3 (1935), "The

Changing Sea Level".
} York, 1931. 